\title{
MONITORS: A NEW EQUITABLE REMEDY?
}

THE traditional concept of courts as passive arbiters of controversies litigated by private parties and the notion of judicial activity as a noncontinuing involvement ${ }^{1}$ have been departed from where complex litigation necessitated more extensive intervention. ${ }^{2}$ For example, when an organization is ordered to hold new elections, courts have appointed a Master in Chancery to supervise performance of the decree. ${ }^{3}$ And receivers are utilized in situations threatening dissipation of disputed property. The appointment of a Board of Monitors to oversee the International Brotherhood of Teamsters is a modern addition to these devices. ${ }^{4}$

In September 1957, thirteen Teamster Union members instituted a class action in the United States District Court for the District of Columbia against the International and its officers to enjoin the holding of the 1957 Miami convention. Plaintiffs requested the appointment of a master or a receiver to supervise the election of delegates to a new convention and asked the court to correct alleged constitutional abuses and corrupt practices in the Union.5 A preliminary injunction issued, ${ }^{6}$ but it was stayed on appeal, 7 and the

1. See 2 Simpson \& Stone, Law and Soctety 1328 (1949); Arnold, Trial by Combat and the New Deal, 47 Harv. L. Rev. 913 (1934); Simpson, Fifty Years of American Equity, 50 HaRv. L. Rev. 171, 224 (1936).

2. Pomeroy, Enuity Jurisprudence $\$ 109$, at 140 (5th ed. 1941); Taylor v. Salmon, 4 My. \& Ch. 134, 141-42, 41 Eng. Rep. 53, 56 (Ch. 1838) (Lord Cottenham).

3. See, e.g., O'Neill v. United Ass'n of Journeymen Plumbers, $348 \mathrm{~Pa} .531,36$ A.2d 325 (1944); Bartlett v. Gates, 118 Fed. 66 (C.C. Colo. 1902) (master to superintend election of corporate directors).

4. Cunningham v. English, (41 L.R.R.M. 49 (D.D.C. 1958)); see Mandlebaum, The Teamster Monitorship: A Lesson For the Futute, 20 FEB. B.J. 125 (1960); Note, 48 GEO. L.J. 178, 182-83 (1959) (Monitors "an ideal balance").

A recent suit against the Carpenters Union requested the appointment of monitors. See 45 LAB. ReL. Rep. 124 (1959).

To the extent that it is possible, procedural problems are omitted from this discussion. See, Note, The Problen of Capacity in Union Suits: A Potpourri of Erie, Diversity and the Federal Rules of Civil Procedure, 68 Y ALE L.J. 1182 (1959); Forkosch, The Legal Status and Suability of Labor Organizations, 28 TEMPLE L.Q. 1 (1954). The word "Monitor" has been used to describe various other institutions. See N.Y. Times, May 31, 1960, p. 41, col. 2 ("Monitor" of du Pont-owned G.M. stock).

5. See Brief for Appellants, p. 3, Brief for Board of Monitors, p. 1-2, English v. Cunningham, 269 F.2d 517 (D.C. Cir. 1959); Cunningham v. Teamsters Union, 40 L.R.R.M. 2650 (D.D.C. 1957).

Apparently there were violations of the constitution and bylaws of the ... Teamsters in the . . 1957 convention, but many of these violations were technical ones and no one seriously believes that a majority of the members desired a different president.

Cox, The Role of Law in Preserving Union Democracy, 72 Harv. L. Rev. 609, 627 (1959).

6. Cunningham v. Teamsters Union, 40 L.R.R.M. 2650 (D.D.C. 1957).

7. Teamsters Union v. Cunningham, 40 L.R.R.M. 2653 (D.C. Cir. 1957). 
convention was held as scheduled; new officers were elected and a new constitution was adopted. Shortly thereafter, plaintiffs, claiming that the convention had been "rigged," sought to nullify its acts and resolutions. A new injunction prohibited inauguration of the newly elected union officials and effectuation of the new constitution pending final determination of the suit. The case was set for trial. After prolonged litigation and negotiation the parties agreed upon a compromise, which was embodied in a consent order, and approved by Judge Letts in January $1958 .^{\circ}$

The basic purpose of the order was to pave the way for a new convention of the International Brotherhood and a new election of officers in accordance with the provisions of the International constitution. ${ }^{10}$ The order permitted the union leaders provisionally to take office ${ }^{11}$ and established a Board of Monitors, to be composed of one representative from the dissident union members, one from the International, and one court appointee jointly nominated by the parties. ${ }^{12}$ The Board, subject to judicial supervision and direction, was to "counsel with" the Teamsters and make "recommendations" to the General Executive Board of the International relevant to internal union democracy and proper financial practices. It was also instructed to draft a model code of local union by-laws, ${ }^{13}$ and was permitted to suggest amendments to the International Constitution. ${ }^{14}$ The decree ordered compensation for the Monitors from union funds, ${ }^{15}$ and provided that when another convention was held, monitorship would terminate. The date for the new convention was placed at the discretion of the Teamsters' General Executive Board, exercisable after one year from the date of the order, but no later than $1962 .^{16}$

Subsequent to approval of the consent decree, the scope of the Board's power was construed by Judge Letts as a charter to conduct "a general house-

8. Cunningham v. English, 41 L.R.R.M. 2022 (D.D.C.), modified, Teamsters Union v. Cunningham, 41 L.R.R.M. 2044 (D.C. Cir. 1957).

9. Cunningham v. English, 41 L.R.R.M. 49 (D.D.C. 1958). The Teamsters claim that they compromised so that the results of the 1957 convention would not be "thwarted for an extended period, with the union remaining under the leadership of its former General President, Dave Beck, and under the government of a rejected constitution." Brief for Appellants, p. 4, English v. Cunningham, 44 L.R.R.M. 2219 (D.C. Cir. 1959).

10. Cunningham v. English, 175 F. Supp. 764, 767 (D.D.C. 1958).

11. The officers "have been permitted to be and to remain in general charge of the affairs of the Teamsters." English v. Cunningham, 269 F.2d 517, 523 (D.C. Cir. 1959). A legal dispute has since developed over the meaning of the word "provisional." The Teamsters claimed that it meant "temporary," while the plaintiffs and monitors read it as meaning "conditional." See Hoffa v. Letts, Civil No. 15676, D.C. Cir., July 21, 1960.

12. Cunningham v. English, 41 L.R.R.M. 49, 50 (D.D.C. 1958). The Board also has a staff of 3 to 5 lawyers.

13. Ibid.

14. Id. at 52 .

15. Ibid.

16. Id. at 51. Compare Binnie \& Manning, The Recerver and Manager in PosSEssion 2 (4th ed. 1960) (power of receiver to manage usually given for definite term). 
cleaning."17 The Court of Appeals, however, held that Monitor recommendations were to deal only with the substantive obligations imposed on defendants by the consent decree. ${ }^{18}$ These obligations are phrased in all-inclusive language, similar to sections of the International Union's constitution:

All persons having custody or management of such funds or properties shall be required to adhere to the recognized legal and equitable standards and obligations imposed upon fiduciaries in the handling of such funds and properties.

No officer of the International ... shall have a personal financial interest which conflicts with the full performance of his fiduciary duties as a representative of the International . . . .19

On their face, these provisions would authorize the Monitors to investigate and make recommendations as to particular union activities never specifically brought to the attention of the court by the plaintiffs. Other obligations, similarly broad, are implied by directives such as those requiring the General Executive Board to "examine and review" the problem of trusteeships imposed on locals.

The enforceability of Monitor recommendations, not clarified by the decree itself, was defined in litigation arising from the Teamsters' refusal to follow several Monitor "Orders of Recommendation." The Monitors petitioned the court for interpretation or modification of the consent decree. Relying on the acknowledged power of a court of equity to adapt a consent decree to changed conditions, ${ }^{20}$ the district court ruled that failure to comply with a Monitor order would subject the defendants to judicial sanction. ${ }^{21}$ On appeal, however, the Circuit Court ruled that the Monitors, according to the decree, were merely advisory, and that their recommendations were not binding on the Teamsters or on the court. ${ }^{22}$ The Monitors could, however, call the court's attention to

17. Cunningham v. English, 175 F. Supp. 764, 767 (D.D.C. 1958).

For a discussion of the validity of consent decrees and the conditions under which they can be modified, see Donoven \& McAllister, Consent Decrees in the Enforcement of Federal Anti-Trust Laws, 46 Harv. L. Rev. 885 (1933).

18. English v. Cunningham, 269 F.2d 517, 522 (D.C. Cir. 1959).

19. The decree is reported in Cunningham v. English, 41 L.R.R.M. 49 (D.D.C. 1958). See Business Week, Sept. 20, 1958, p. 130 (order loosely drafted because otherwise difficult to make it acceptable to both parties).

20. Donovan \& McAllister, supra note 17, at 895-96; United States v. Swift \& Co., 286 U.S. 106, 114 (1932) ("We are not doubtful of the power of a court of equity to modify an injunction in adaption to changed conditions, though it was entered by consent.").

21. Cunningham v. English, 175 F. Supp. 764 (D.D.C. 1958). The court also ruled that the new Teamster election was to be held at such time as the Monitors would recommend (subject to court approval), rather than in one year, as specified by the consent decree. Id. at 768-69. Compare Higham v. Gaw, 43 L.R.R.M. 2188 (N.D. Ohio 1958) (Monitors only advisory).

22. English v. Cunningham, 269 F.2d 517 (D.C. Cir. 1959). Certiorari was denied, although Justice Frankfurter termed the appointment "an unusual manifestation of equity powers." English v. Cunningham, 361 U.S. 908, 909 (1959). 
violations of the consent decree, and the court, after a hearing, could order the defendants to comply with the decree. "[A]ction of the court must rest upon its decrees, not upon the Monitors' recommendations as such . . .."23

This Comment attempts no affirmative answer to the issues posed by allegedly corrupt and undemocratic labor unions. The purpose is rather to determine the extent to which monitorship departs from previous forms of equitable relief, such as the master or receiver, and to assess the utility of monitorship as a technique for judicial supervision of private organizations.

\section{Masters, Receivers, and Monitors-A Coniparative Evaluation Masters}

The master is an advisory official appointed by a court to assist in the handling of a particular case. ${ }^{24}$ Originally he was a clerk to the Cancellor, performing such mechanical duties as acknowledging deeds and taking oaths or affidavits. ${ }^{25}$ The current duties of the office vary widely according to the particular jurisdiction. Occasionally the master will be relegated to a strictly clerical position. Frequently, however, he is authorized to conduct investigations, ${ }^{26}$ recommend sanctions ${ }^{27}$ or reach conclusions of fact or law $;^{28}$ for example, he might verify accounts, determine the value of property or compute damages. ${ }^{29}$ Investigations of a master, usually conducted through adversary hearings, ${ }^{30}$ are similar to an actual trial. The master can rule upon the admissibility of evidence in proceedings before him. ${ }^{31}$ In nonjury actions, his findings of fact will be accepted by the court unless they are "clearly erroneous." 32 Federal courts are empowered to make references to a master by Rule 53 of the Rules of Civil Procedure, which defines the master as "a

23. 269 F.2d at 523 .

24. See, e.g., Kimberly v. Arms, 129 U.S. 512 (1889).

25. Bryant, The Office of Master in Chancery: Early English Development, 40 A.B.A.J. 498 (1954). See generally Coel v. Glos., 232 Ill. 142, 83 N.E. 529 (1907) (master purely a ministerial office); Hards v. Burton, 79 Ill. 504 (1875) (same); 1 Spence, The Equity Jurisdiction of the Court of Chancery 359-60 (1846).

26. E.g., Iowa R. Crv. P. 207-14 (1951) ; GA. Code ANN. \$ 10-102 (1936); In re Utilities Power \& Light Corp., 90 F.2d 798 (7th Cir.), cert. denied, 302 U.S. 742 (1937).

27. See, e.g., Fla. Stat. Ann. \$ 56.02(6) (1943).

28. E.g., Ga. Code AnN. $\S 10-101$ to 10-501 (1935) ; Tenn. Code Ann. $\S 20-1405$ (1955) ; cf. Ward v. Town Tavern, 191 Ore. 1, 36, 228 P.2d 216, 231 (1951); Bryant, The Office of Master in Chancery-Development and Use in Illinois, 49 Nw. U.L. REv. 458 (1954).

29. See, e.g., Ransom v. Winn, 59 U.S. (18 How.) 295 (1855) ; Springle's Heirs \& Adm'rs v. Shields, 17 Ala. 295 (1850); Saltus v. Pruyn, 18 How. Pr. (N.Y.) 512 (N.Y. Sup. Ct. 1859).

30. FED. R. CIV. P. 53(d) (1).

31. FED. R. Crv. P. 53(c).

32. Fed. R. CIv. P. 53(e) (2). Compare Milasinovich v. Serbian Progressive Club, $377 \mathrm{~Pa} .385,388,105 \mathrm{~A} .2 \mathrm{~d} 149,150$ (1954) ("The report of the receiver cannot be regarded as a master's findings of fact and conclusions of law or as a recommended decree."). 
referee, an auditor [or] an examiner" who has the "obligations of a judicial officer." 33 Rule 53 references are confined to exceptional cases, particularly lengthy and complex litigation which might consume an undue amount of the court's time or confuse a jury, ${ }^{34}$ and are most appropriate in situations requiring personal action, specialized knowledge, or continuous supervision. ${ }^{35}$

A master may, in the course of his duties, indirectly interfere with private organizations. For example, he might be called upon to supervise a corporate or a union election. ${ }^{38}$ But the office was neither intended nor designed to function in a managerial capacity. ${ }^{37}$

\section{Noninsolvency Receivers ${ }^{38}$}

A receiver is a court official designated to hold, manage, or liquidate property ${ }^{30}$ on behalf of the party ultimately entitled to ownership or control ${ }^{40}$

33. FED. R. Civ. P. 53(a).

34. ABA, Report of the Committee on Practice and Procedure in the Trial of Antrtrust CAses 12-15 (1954) (Rept. 15); Kaufman, Masters in the Federal Courts: Rule 53, 58 Colum. L. Rev. 452 (1958).

35. Bryant, The Office of Master in Chancery-Development and Use in Illinois, 49 Nw. U.L. REv. 458, 476 (1954) ; Kaufman, supra note 34, at 455.

36. See note 3 supra.

37. Cf. Quinby v. Conlan, 104 U.S. 420 (1881); Kimberly v. Arms, 129 U.S. 512 (1889).

38. Because of the different considerations involved and the extent to which the subject has already been discussed, analysis of the insolvency or the bankruptcy receiver has been omitted.

A "special master" may in effect be a receiver. New England Oil Ref. Co. v. Canada Mexico Oil Co., 274 Mass. 191, 174 N.E. 330 (1931).

Another form of judicial intervention, now primarily of historical interest, was visitatorial jurisdiction over corporations in equity. In modern terms, visitatorial power is the right of a state, usually initiated by the Attorney General, to investigate and correct the abuses of corporate directors through judicial scrutiny and remedies. It offered a corrective for future abuses as well as punishment for old ones in cases of injury to the public. But the visitatorial concept provided a type of jurisdiction or cause of action, and not a remedy or method of reaching a decision. Moreover, it envisioned sporadic litigation, and not continuous supervision, and thus differed from monitors. See Pound, Visitatorial Jurisdiction Over Corporations In Equity, 49 HARv. L. Rev. 369 (1936).

Chancery will not exercise purely visitatorial powers over unions. Dragwa v. Federal Labor Union 23070, 136 N.J. Eq. 172, 41 A.2d 32 (Ch. 1945); cf. State v. Milwaukee Chamber of Commerce, 47 Wis. 670, 679-80, 3 N.W. 760, 763-64 (1879); Kawfield Oil Co. v. Illinois Ref. Co., 196 Okla. 75, 35 P.2d 961 (1934). But see Figge v. Bergenthal, 130 Wis. 594, 110 N.W. 798 (1907).

"The courts also observed that the modern state Attorney General has been so preoccupied with other affairs of state that he would be unlikely to take steps available to him to visit ..." Ashley v. Keith Oil Corp., 73 F. Supp. 37, 56 (1947). Compare Gower, Modern Company Law 515-17 (1954) (British minority shareholders right to petition Board of Trade for investigation).

39. State ext rel. Givens v. Superior Court, 233 Ind. 235, 117 N.E.2d 553 (1954); Blacx, Law Dictionary 1433 (4th ed. 1951).

40. See, e.g., Title Guarantee \& Trust Co. v. 457 Schenectady Ave., Inc., 235 App. Div. 509, 512, 257 N.Y. Supp. 413, 417 (1932); Thom v. Pittard, 62 Fed. 232 (4th Cir. 1894). 
when that property is threatened with irreparable and imminent harm. ${ }^{41}$ Arising from the inadequacy of injunctions in protecting such property, receivership was a common remedy in England by the 16th century, and was incorporated into United States law by a Supreme Court rule adopted in about $1800 .{ }^{42}$ In most jurisdictions, courts of equity have an inherent authority to establish a receivership; 43 in a few, however, this device exists only by statutory authority. ${ }^{44}$ In discharging his duties a receiver may take possession of assets, collect debts, pay salaries, and perform contracts. ${ }^{45}$ Receivers have been appointed to enforce regulation of natural resource production, ${ }^{40}$ to collect and distribute taxes for a municipality, ${ }^{47}$ to restrain an organization from repeated criminal conduct, ${ }^{48}$ and to prevent injury to a municipality by ensuring continued operation of a railroad line. ${ }^{49}$ The noninsolvency receiver is most commonly employed in the corporate context. But the office has also been utilized to supervise labor union locals, usually where officials of the local are accused of rigging elections or misappropriating union funds $;{ }^{50}$ since 1940 , six local union receiverships have been granted and one denied. ${ }^{51}$

41. Pouliot v. West India Fruit Co., 283 Mass. 182, 186 N.E. 52 (1933) ; Dvorin v. Greenberg, 106 N.J. Eq. 495, 151 Atl. 95 (Ch. 1930); Katz v. DeWolf, 151 Wis. 337, 138 N.W. 1013 (1912).

42. 1 Spence, Equitable Jurisdiction of the Court of Chancery 673 (1846).

Thought to have been promulgated shortly after enactment of the United States Practice Act of 1792, Supreme Court Equity Rule No. 90 was in existence at the passage of the New Equity Rules of 1912.

Rule 90 . In all cases where the rules prescribed by this court or by the circuit court do not apply, the practice of the circuit court shall be regulated by the present practice of the High Court of Chancery in England . . . .

43. E.g., Burnrite Coal Briquette Co. v. Riggs, 274 U.S. 208 (1927) ; Miller v. M. E. Smith Bldg. Co., 118 Neb. 5, 223 N.W. 277 (1929) ; Sinclair v, Moore Cent. R. Co., 228 N.C. $389,395,45$ S.E.2d 555,560 (1947).

44. E.g., Nelson v. Toluca State Bank, 334 Ill. 83, 165 N.E. 191 (1929). Federal courts may grant equitable remedies without regard to state law. Black \& Yates, Inc. v. Mahogany Ass'n, 129 F.2d 227 (3d Cir. 1942).

45. See, e.g., Union Bank v. Kansas City Bank, 136 U.S. 223 (1890); Southern Ry. Co. v. American Brake Co., 76 Fed. 502 (4th Cir. 1896); New England Ry. Co. v. Carnegie Steel Co., 75 Fed. 54 (1st Cir. 1896).

46. Patton v. State, 62 S.W.2d 381 (Tex. Civ. App. 1933); see Note, 43 Y ALE L.J. 1156 (1934) (receiverships suggested to enforce New Deal legislation).

47. Broadhurst v. Commissioners, 195 N.C. 439, 142 S.E. 477 (1928).

48. Columbian Athletic Club v. State ex rel. McMahan, 143 Ind. 98, 40 N.E. 914 (1895) (systematic promotion of illegal prizefights); Kahan v. Alaska Junk Co., 111 Wash. 39, 189 Pac. 262 (1920) (robbery) (dictum).

49. Milltown Lumber Co. v. Town of Milltown, 150 Ga. 55, 102 S.E. 435 (1920).

50. See, e.g., Gilligan v. Moving Picture Mach. Operators, Local No. 244,135 N.J. Eq. 484, 39 A.2d 129 (Ct. Err. \& App. 1944); Collins v. International Alliance of Theatrical Stage Employees, 119 N.J. Eq. 230, 182 Atl. 37 (Ch. 1935).

51. Fitzgerald v. Abramson, 89 F. Supp. 504 (S.D.N.Y. 1950) ; Kegg v. Bianco, 89 Pitt. L.J. 447 (C.P. 1941); Mursener v. Forte, 186 Ore. 253, 205 P.2d 568 (1949); Robinson v. Nick, 235 Mo. App. 461, 136 S.W.2d 374 (1940); Duke v. Franklin, 117 
Despite its long history, receivership law is unsettled. Courts justify denial of receivership by categorizing it as an unusual remedy ${ }^{\mathbf{5 2}}$ but, in view of the extensive use of the device, this categorization is unrealistic. ${ }^{53}$ The plaintiff's motive in bringing suit is supposedly irrelevant, ${ }^{54}$ but some receiverships are denied when bad faith is shown. ${ }^{55}$ While the courts have repeatedly emphasized that receivership must be ancillary to other relief, ${ }^{56}$ receivers have been requested and granted as the primary object of a suit. ${ }^{57}$ And while plaintiffs formerly were required to prove the existence of danger to a property right, ${ }^{58}$ danger to some "substantial interest" will now usually suffice. ${ }^{59}$

Ore. 297, 162 P.2d 141 (1945); Silbilia v. Western Electric Employees Ass'n, 142 N.J. Eq. 77, 59 A.2d 251 (Ct. Err. \& App. 1948). Receivership was denied in Gilligan v. Moving Picture Mach. Operators, Local 244, 135 N.J. Eq. 484, 39 A.2d 129 (Ct. Err. \& App. 1944).

For commentary on the pre-1940 use of such receiverships, see Note, 42 YaLE L.J. 1244, 1248 (1933).

52. [R] eceivership is the most drastic remedy and the most expensive luxury known to the realm of law.

Furrer v. Nebraska BIdg. \& Inv. Co., 108 Neb. 698, 710, 189 N.W. 359, 364 (1922). Receivership is frequently called a "last resort." See, e.g., Home Mortgage Co. v. Ramsey, 49 F.2d 738 (4th Cir. 1931); Royal Union Life Ins. Co. v. Boynton, 54 S.D. 85, 222 N.W. 596 (1928).

53. See Burleson v. Hayutin, 130 Colo. 58, 62, 273 P.2d 124, 127 (1954).

54. In re Metropolitan Ry. Receivership, 208 U.S. 90 (1908) ; Dickerman v. Northern Trust Co., 176 U.S. 181, 190 (1900) ; Portage Brick Co. v. North Indiana Brick Co,, 189 Ind. 639, 128 N.E. 847 (1920).

55. Neff v. Progress Bldg. Materials Co., 139 N.J. Eq. 356, 359, 51 A.2d 443, 445 (Ch. 1947) (not convinced of complainant's sincerity); Indianapolis Dairymen's Co-op v. Bottema, 266 Ind. 237, 247-48, 79 N.E.2d 399, 40405 (1948) (written demand on director shows plaintiff's true motive); Best v. Southern Hide Co., 170 La. 997, 129 So. 614 (1930) (plaintiff really aggrieved that she was not elected director).

56. Receivership "is provisional and cannot be the ultimate object of the action." Pudy v. Humphrey, 82 N.Y.S.2d 92, 192 Misc. 309, 318 (Sup. Ct. 1947) ; Hoiles v. Watkins, 117 Ohio St. 165, 157 N.E. 557 (1927); Willson v. Waltham Watch Co., 293 Fed. 811 (D. Mass. 1923).

57. See, c.g., Gibbons Mfg. Co. v. Milan, 17 S.W.2d 844, 847 (Tex. Civ. App. 1929) (prayer for general relief sufficient to authorize granting receiver); State $e x$ rel. Goff v. O'Neil, 205 Minn. 366, 286 N.W. 316 (1939) ; Indianapolis Dairymen's Co-op v. Bottema, 226 Ind. 237, 246, 79 N.E.2d 399, 403 (1948); Guaranty Laundry Co. v. Pulliam, 200 Okla. 185, 188-89, 191 P.2d 975,979 (1948).

Reorganization receivership developed under the fiction that liquidation was the ultimate remedy. See Arnold, The Folklore of Caprtalism 235-41 (1st ed. 1937). A Louisiana statute has been interpreted to grant receivership as a substantive right, and not as an ancillary remedy. Kohler v. McClellan, 156 F.2d 908, 911-13 (5th Cir. 1946).

58. See, e.g., Gray v. Council of Newark, 9 Del. Ch. 171, 79 Atl. 735 (1911); Engleburg v. Tonkel, 140 Miss. 513, 106 So. 447 (1926).

59. 75 C.J.S. Receivers $\S 19$ (1952). Cf. Kenyon v. City of Chicopee, 320 Mass. 528, 70 N.E.2d 241 (1946).

Receivership is also refused often because plaintiff's allegations are insufficiently specific or undocumented. See Hall v. McLuckey, 134 W. Va. 595, 607, 60 S.E.2d 280, 287 (1950) ; Gillies v. Pappas Bros. \& Gillies Co., 138 N.J. Eq. 202, 47 A.2d 424 (Ch. 1946); Ex parte American Life Insurance Co., 262 Ala. 543, 80 So. 2d 299 (1954); Schuster v. Largman, 
The grounds upon which the appointment of a receivership is granted or denied-fraud, ${ }^{60}$ gross mismanagement, ${ }^{61}$ or dissension ${ }^{62}$-are deceptively easy to establish. To warrant this remedy, a fraud must in practice be active and cause a clear and substantial loss to the complainant ; $^{63}$ but because fraud incorporates the element of intent, ${ }^{64}$ which is notoriously difficult to prove, the fraud concept is inherently unpredictable. The amorphous concept of gross mismanagement is equally demanding, because the plaintiff is, in actual court practice, required to demonstrate that the defendant acted in bad faith. ${ }^{65}$ Finally, the dissension criterion goes further than mere disagreement; to permit receivership, dissension must paralyze the normal operations of the organization. ${ }^{66}$ The stringency of these ostensibly clear standards is reinforced

$308 \mathrm{~Pa} .520,524,162$ Atl. 305, 308 (1932) (allegations not of that specific nature calling for interposition of equity); e.g., Lichens Co. v. Standard Commercial Tobacco Co., 28 Del. Ch. 220, 40 A.2d 447 (Ch. 1944) ; Draper v. J. Gr Robinson Lettuce Farms, 164 Wash. 8, 2 P.2d 661 (1931).

60. E.g., Lichens Co. v. Standard Commercial Tobacco Co., 28 Del. Ch. 220, 40 A.2d 447 (Ch. 1944) ; Gillies v. Pappas Bros. \& Gillies Co., 138 N.J. Eq. 202, 47 A.2d 424 (Ch. 1946) ; Draper v. J. G. Robinson Lettuce Farms, 164 Wash. 8, 2 P.2d 661 (1931).

61. E.g., Cook v. Cook, 270 Mass. 534, 170 N.E. 455 (1930). Mismanagement is used as a complainants' catch-all. See, e.g., Rabinowitz v. Steinberg, 112 N.Y.S.2d 758 (App. Div. 1952); Faulk v. Futch, 147 Tex. 253, 214 S.W.2d 614 (1948); Hall v. McLuckey, 134 W. Va. 595, 60 S.E.2d 280 (1950).

62. E.g., Grand Lodge K. P. v. Shorter, 219 Ala. 293, 122 So. 36 (1929) ; Mentzer v. Mentzer Bros. Lumber Co., 137 Wash. 630, 243 Pac. 832 (1926) ; Hlawati v. MaederHlawati Co., $289 \mathrm{~Pa} .233$, 137 Atl. 235 (1927).

Several cases have also justified the granting of receivership on the basis of "public interest." E.g., Quincy M. \& P.R. Co. v. Humphreys, 145 U.S. 82, 101 (1892) ; Sinclair v. Moore Cent. R. Co., 228 N.C. 389, 396, 45 S.E.2d 555, 560 (1947). In England, receivers are appointed where they appear "just and convenient." KERR, RECEIVERS 1 (12th ed 1952).

63. See, e.g., Milasinovich v. Serbian Progressive Club, 369 Pa. 26, 84 A.2d 571 (1951) (corporate assets given to communist organizations); Anglo-American Royalties Corp. v. Brentnall, 167 Okla. 305, 29 P.2d 120 (1934); Masin v. National Box \& Lumber Co., 17 N.J. Super. 380, 86 A.2d 27 (1952) ; Firebaugh v. McGovern, 404 Ill. 143, 88 N.E.2d 473 (1949).

64. Indianapolis Dairymen's Co-op v. Bottema, 266 Ind. 237, 250, 79 N.E.2d 399, 406 (1948); Neidringhaus v. William F. Niedringhaus Inv. Co., 329 Mo. 84, 124, 46 S.W.2d 828,842 (1931) (not proceeded from bad motives) ; Patton v. Nicholas, 154 Tex. 385, 394, 279 S.W.2d 848, 854 (1955) ("malicious" suppression of dividends).

65. See Orth v. Transit Inv. Corp., 132 F.2d 938 (3rd Cir. 1942); Kinnebrew v. Louisiana Ice Co., 216 La. 472, 43 So. $2 d 798$ (1949); Indianapolis Dairymen's Co-op v. Bottema, 266 Ind. 237, 79 N.E.2d 399 (1948); Little Warrior Coal Co. v. Hooper, 105 Ala. 665, 17 So. 118 (1895). There may, of course, be cases of flagrant good faith mismanagement, but courts have so far been hesitant to intervene where defendant's motives were unimpeached.

66. "Dissatisfaction with existing management and ... a deadlocked condition of the stockholders and directors is not of itself . . . sufficient ground for the appointment of a receiver." Macon Lumber Co. v. Bishop \& Collins, 229 F.2d 305, 307 (6th Cir. 1956) ; Dorf v. Hill Bus Co., 140 N.J. Eq. 444, 54 A.2d 761 (Ct. Err. \& App. 1947) (deadlock among shareholders, but corporations operating effectively); Krall v. Krall, 141 Conn. 325, 106 A.2d 165 (1954). 
by a judicial tendency to limit receivership appointment by applying several collateral tests. Ordinarily unarticulated, these are: the judge's opinion of a receiver's probable achievements in the context of the particular litigation, ${ }^{67}$ the solvency of the organization, ${ }^{B 8}$ the plaintiff's acquiescence in the conduct complained of, ${ }^{60}$ and the expected duration of the receivership. ${ }^{70}$ For example,

67. See Kohler v. McClellan, 156 F.2d 908 (5th Cir. 1946); Orth v. Transit Inv. Corp., 132 F.2d 938, 943 (3rd Cir. 1942) (considering past achievements in suit to wind up receivership); Lowe v. Copeland, 13 P.2d 522, 526 (Cal. D. Ct. App. 1932); Mínotte E. Chatfield Co. v. Coffey Laundries, 11 Conn. 497, 150 Atl. 511 (1930); Steenrod v. L. M. Gross Co., 334 IIl. 362, 364, 166 N.E. 82, 84 (1929); cf. Indianapolis Dairymen's Co-op v. Bottema, 266 Ind. 237, 79 N.E.2d 399 (1948).

68. Compare Bator v. United Sausage Co., 138 Conn. 18, 23, 81 A.2d 442, 444 (1951) (no receiver when "business has been conducted profitably" and "assets of the company have been increased."), and Kinnebrew v. Louisiana Ice Co., 261 La. 472, 43 So. 2d 798 (1949) (defendant's operations reflect a substantial profit), with Iincoln Printing Co. v. Middle West Utilities Co., 74 F.2d 779 (7th Cir. 1935) (financial catastrophe inevitable), and Gibbons Mfg. Co. v. Milan, 17 S.W.2d 844 (Tex. Civ. App. 1929) (main plant virtually closed), and Anglo-American Royalties Corp. v. Brentnall, 167 Okla. 305, 29 P.2d 120 (1934) (company almost insolvent), and Mirror Lake Co. v. Kirk Sec. Corp., 98 Fla. 946, 124 So. 719 (1929) (near insolvency), and Scholl v. Allen, 237 Ky. 716, 36 S.W.2d 353 (1931) (same), and Faulk v. Futch, 147 Tex. 253, 214 S.W.2d 614 (1948) (lost every month except one). For contrary protestations, see Central Land Co. v. Sullivan, 152 Ala. 360, 44 So. 644 (1907) ; Hall v. City Park Brewing Co., 294 Pa. 127, 143 Atl. 582 (1928); Zwick v. Security State Bank, 186 Minn. 308, 243 N.W. 140 (1932).

69. See Beard v. Achenbach Memorial Hospital Ass'n, 170 F.2d 859 (10th Cir. 1948); Ashley v. Keith Oil Corp., 73 F. Supp. 37 (D. Mass. 1947) ; Fennell v. J. Comer Jones Power \& Pump Co., 270 Mass. 482, 170 N.E. 453 (1930) ; Patton v. Nicholas, 154 Tex. 385, 388, 279 S.W.2d 848, 850 (1955) ; Deauville Corp. v. Blount, 157 Fla. 322, 25 So. 2d 812 (1946). But see Franklin Nat'l Bank v. Kennerly Coal \& Coke Co., 300 Pa. 479, 150 Atl. 902 (1930).

70. Although not a "test," the predisposition of the particular judge toward receivership as an institution is often a determinative factor. Compare Zwick v. Security State Bank, 186 Minn. 308, 309, 243 N.W. 140, 141 (1932) ("Receiverships are notoriously expensive and rightly considered a last resort."), and Dvorin v. Greenberg, 106 N.J. Eq. 495, 496-97, 151 Atl. 95, 96-97 (Ch. 1930), and Helm v. Talmadge, 40 S.W.2d 496, 499 (1931), with Burleson v. Hayutin, 130 Colo. 58, 273 P.2d 124 (1954), and Bowen v. Bowen-Romer Flour Mills Corp., 114 Kan. 95, 97, 217 Pac. 301, 303 (1923). Many of the statements made may, of course, be subsequent rationalizations as well as prior attitudes.

Courts frequently add that the appointment of a receiver is a matter for the trial court's discretion. E.g., Carolina Portland Cement Co. v. Baumgartner, 99 Fla. 987, 128 So. 241 (1930) ; Pereira v. Wulf, 83 Mont. 343, 272 Pac. 532 (1928). In practice, this seems to mean that while an appellate court will vacate an appointment, it will rarely reverse a lower court denial of receivership. See Indianapolis Dairymen's Co-op v. Bottema, 226 Ind. 237, 247, 79 N.E.2d 399, 404 (1948).

Confusion is compounded by the courts' manipulation of legal labels. See Rohrlick, Suits in Equity by Minority Stockholders as a Means of Corporate Control, 81 U. PA. L. Rev. 692, 698 (1933) ; Note, 20 MinN. L. Rev. 657, 666 (1936).

Although the courts speak of receivership as an isolated problem, appointment has also been denied because the ultimate right seemed doubtful. See, e.g., Neall v. Hill, 
by considering the probable success of the receivership, a court avoids the expense and disruptive effect of a futile appointment ; and courts rarely install receivers over prosperous and efficient organizations, apparently on the theory that it is unwise for a court to take control of an effective organization, even though the existing management might be fraudulent.

The noninsolvency receivership represents a more extensive equity interference with private organizations than does the master. A master is an instrument intended primarily to enable the court to reach a just and speedy decision. In contrast, receivership is a remedy. In order effectively to protect the rights of the litigant ultimately prevailing, a receiver is ordinarily required to take control of and occasionally to manage the organization. Both receivers and masters might have been used to assist the court and the parties in disposing of the Teamsters litigation. The aggrieved rank and filers had charged violation of twenty-nine different provisions of the union constitution, including undemocratic election procedures during the 1957 convention, widespread mishandling of union funds for personal advantage, violation of $\mathrm{fi}$ duciary obligations, unconstitutional continuation of local trusteeships, gangster influences in local union affairs, and disregard of intra-union disciplinary procedures. ${ }^{71}$ These allegations, if proven, would seem to meet the receivership criteria of gross mismanagement and fraud. Moreover, although the reluctance of courts to interfere with prosperous organizations might have dissuaded the judge from resorting to receivership, the requirement of irreparable and imminent harm to property or other substantial interests would seem to be satisfied by the deprivation of a fair election and the danger to union funds. Therefore, Judge Letts could have adopted one of several courses of action. He could have placed the Teamsters in receivership pendente lite, ${ }^{72}$ either removing the incumbent officers or permitting them to remain in office with severely restricted authority. If plaintiffs proved their allegations at trial, he might have appointed a Rule 53 master to supervise a new election ${ }^{73}$ and to audit the books of the International, perhaps coupled with a mandatory injunction compelling the institution of new accounting procedures and termination of local trusteeships within a reasonable time. ${ }^{74}$ If necessary, a re-

16 Cal. 146, 76 Am. Dec. 508 (1860); Fischer v. Superior Court, 110 Cal. 129, 42 Pac. 561 (1895) ; cf. Bator v. United Sausage Co., 138 Conn. 18, 81 A.2d 442 (1951) (dissolution requested as ultimate right); Patton v. Nicholas, 154 Tex. 385, 394, 279 S.W.2d 848,854 (1955).

71. Cunningham v. Teamsters, 40 L.R.R.M. 2650 (D.D.C. 1957); Cunningham v. English, 41 L.R.R.M. 49 (D.D.C. 1958).

72. A typical reaction is, "It would be intolerable for the Government to appoint outsiders to act as receivers." Cox, The Role of Law in Preserving Union Democracy, 72 HARv. L. Rev. 609, 634 (1959).

73. Professor Cox argues that a master would be relatively ineffective in holding a union election, but he cites only contrary examples. Id. at 626 .

74. See City Nat'l Bank v. Pigg, 63 S.W.2d 327 (Tex. Civ. App. 1933) (mismanagement can be prevented by restraining order); Bassett v. Atwater, 65 Conn. 355, 32 Atl. 937 (1895) (mandamus). See also, Morehead Mfg. Co. v. Washtenaw, Circuit Judge, 254 
ceiver could have been appointed until the objectives of the final decree had been accomplished. Alternatively, the judge could have used the threat of a receiver to secure compliance with the decree by granting a receivership conditioned on defendants' failure fully to comply with the terms of the decision. ${ }^{76}$ Instead, Judge Letts chose to accept the proposal for a Board of Monitors, which had been formulated by the litigants and embodied in the consent decree tendered by them.

\section{Monitors}

The Teamster Monitorship is, of course, a creature of a particular consent decree. Nevertheless, analysis of this example may reveal some of the general problems which a court must consider in accepting such consent decrees. Moreover, since widespread use of such decrees in the future is unlikely, the attributes of monitorship might also be examined to determine whether courts might impose such a remedy without defendant's consent.

Unlike a receiver, a monitorship does not manage the organization, for the recommendations of the Board are not implemented by the International unless the incumbent officers agree, or unless the district court adopts the recommendation as its own order. ${ }^{76}$ Thus, the officers of the Teamsters Union have remained provisionally in power while the Monitors have set up a separate office and retained their own counsel and staff. ${ }^{77}$

The primary function of monitorship is to investigate the affairs of the association and to recommend curative measures. Although courts of equity have frequently employed masters to perform similar tasks, monitor procedures differ significantly. The master makes his recommendations to the court, ${ }^{78}$ whereas monitors are in most instances required to place their recommendations before the defendants and to resort to court enforcement only when these overtures have failed.79 Monitors are thus conceived of as a device to elicit the cooperation of the defendants in settling many of the technical problems which would otherwise require judicial hearing and decision. ${ }^{80}$

In this sense, monitors might fruitfully be compared to labor mediators, with their ability to maintain day-to-day contact short of the formal court-litigant

Mich. 697, 698, 236 N.W. 911, 912 (1931) (dissipation of profits restrained without receivership).

75. See, e.g., Rugger v. Mt. Hood Electric Co., 143 Ore. 193, 194, 21 P.2d 1100, 1101 (1933) (receiver appointed only if stock not returned); Gilligan v. Moving Picture Mach. Operators, 135 N.J. Eq. 484, 39 A.2d 129 (Ct. Err. \& App. 1944) (receiver denied with right to renew it unless constitution amended).

76. See text accompanying notes 20-23 supra.

77. Interview with Lawrence Cohen, staff member of Monitors, in New Haven, Conn., 1960; English v. Cunningham, 45 L.R.R.M. 2461 (D.C. Cir. 1960).

78. Fed. R. Crv. P. 53(e) (1) ; 5 Moore, Federal Practice $\$ 53.10$ (2d ed. 1951).

79. Hoffa v. Letts, Civil No. 15676, D.C. Cir., July 21, 1960.

80. Ibid. Cunningham v. English, 175 F. Supp. 764 (D.D.C. 1958) ; English v. Cunningham, 269 F.2d 517, 522 (D.C. Cir. 1959). 
relation. The monitor's ability to induce cooperation may be impaired, however, by two characteristics which differentiate them from mediators. First, they are not called in to arrange a compromise between conflicting interests; rather, their purpose is the furtherance of objectives already laid down by the court. Second, they can and do resort to judicial compulsion when their recommendations are not adopted. Endowed with these policeman-like attributes, monitors cannot successfully assume the guise of uncommitted observers so carefully nurtured by mediators and so essential to their success.

Also, monitors may conduct independent ex parte investigations. ${ }^{81}$ The master, on the other hand, sits in place of the judge as an arbiter of the evidence presented by the parties in interest. ${ }^{82}$ Whether monitors may conduct such hearings in addition to their investigations is unclear. If the monitor board does not hold hearings, the litigants cannot control the evidence brought before the monitors, nor can they rebut the evidence obtained until a report to the court has been filed. The importance of this handicap will be diminished if the court holds a hearing at which the adversely affected party has an opportunity to present his case. Such hearings have been held when the district court passed upon recommendations of the Teamsters Monitors ${ }^{83}$ indeed, hearings may be required as a matter of due process. ${ }^{84}$ Even with a court hearing, however, the detriment of the litigants will not fully be repaired if the monitor's fact findings are accorded the same weight as those of a master in a nonjury action, which, under Rule 53, may be upset only if they are "clearly erroneous." 85 The defendant, for example, will have lost the opportunity, which he would have had at trial or before a master, to have his case judged on the "preponderence of the evidence." 86 Instead he will carry the

81. This would appear to be implied from Monitor power to make recommendations. An example is the Monitor investigation of the "Sun Valley" dealings. See Mandelbaum, The Teamster Monitorship: A Lesson for the Future, 20 FED. B.J. 133-35 (1960).

82. 5 Moore, Federal Practice $\$ 53.04$ (2d ed. 1951); Hoe v. Scott, 87 Fed. 220 (C.C.D.N.J. 1898)

83. English v. Cunningham, 269 F.2d 517, 522-23 (D.C. Cir. 1959); cf. Hoffa v. Letts, Civil No. 15676, D.C. Cir., July 21, 1960.

84. The general rule is that when official acts are based on "individual" as opposed to "general" grounds and the facts to be determined are consequently "adjudicative" as opposed to "legislative," due process requires a right to a hearing. See Davrs, AparrnINSTRATIVE LAW $\$ 7.04$ (1958); Londonder v. City and County of Denver, 210 U.S. 373 (1908); Yakus v. United States, 321 U.S. 414 (1944); Morgan v. United States, 304 U.S. 1, 113 (1937) ("Those who are brought into contest with the government in a quasijudicial proceeding aimed at control of their activities are entitled to be fairly advised of what the Government proposes and to be heard upon its proposals before it issues its final command.").

85. FED. R. CIV. P. 53(e) (2).

86. Since there is never a jury in a Monitor hearing, the fact that the "clearly erroneous" test does not apply to a master's report in a jury case is irrelevant.

"Preponderance of the eyidence" is only a general rule of trial procedure, of course, 
far heavier burden of proving that the adverse version of the facts is "clearly erroneous."

The evidentiary weight of monitor recommendations has not been ruled upon in the Teamster litigation. Parties could argue that imposition of the "clearly erroneous" test by the court, without a hearing before the monitors, would deprive them of their right to a fair hearing. ${ }^{87}$ On the other hand, if a consent decree explicitly or by interpretation includes such a test, the parties may be barred from raising this defense by their acquiescence. ${ }^{88}$

Another aspect of the Monitor's ex parte investigating power is the possibility that monitors may be used to investigate allegations of the parties before trial on the merits. The consent decree in the Teamster litigation does not impose specific obligations upon the several defendants; rather, it enunciates broad duties similar to the general fiduciary provisions of the union constitution. Under this decree, Teamster Monitors have discovered and called the court's attention to violations of the union constitution which the plaintiffs did not specifically allege. ${ }^{89}$ Thus the court, through its appointed officers, has in practice assumed part of the investigatory and prosecutory role which the parties normally perform.

This use of monitorship transfers some control over the litigation to court officers $^{90}$ and shifts the financial burden of prosecuting the suit from the plaintiff to the organization's treasury. While this apportionment of costs need not be an inevitable attribute of monitorship, in practice plaintiff's would probably not request monitors if costs were contingent upon the outcome of the suit, for, at the same financial risk, they could retain full control over the suit without monitor interference. ${ }^{91}$

Many questions regarding the propriety of these monitor functions probably cannot be raised when monitorship is established under a consent decree. By acquiescing, the parties may have waived those elements of their right to a fair judicial hearing which monitor investigations offend. Nevertheless, in approving such procedures, the court must consider whether the remedy is a

since either party may be weighed down by presumptions which shift the burden of proof. Smith v. Hill, 232 Mass. 188, 122 N.E. 310 (1919).

In a proceeding before a master, both parties must be given a chance to present evidence. FED. R. CIv. P. 53(d) (1). For concern with rights of receivers to proceed without representation of all parties, see Orth v. Transit Inv. Corp., 132 F.2d 938, 942 (3d Cir, 1942).

87. Cf. Heiner v. Donnan, 285 U.S. 312 (1932) ; Commissioner v. Clark, 202 F.2d 94 (7th Cir. 1953).

88. In arbitration held under a voluntary arbitration agreement, a party cannot judicially attack an $c x$ parte inquiry to which he has consented in the agreement. See In re Arbitration Puget Sound Bridge \& D. Co. v. Lake Washington Shipyards, 1 Wash. 2d 401, 96 P.2d 257 (1939).

89. Cunningham v. English, 175 F. Supp. 764 (D.D.C. 1958), aff'd, 269 F.2d 517

(D.C. Cir. 1959), aff'd as modified, 269 F.2d 539 (D.C. Cir. 1959).

90. See text at notes 85-88 supra and 93-94 infra.

91. Livingston, The American Stockholder 49-59 (1958). 
proper judicial device and whether it serves the best interests of all concerned. The enormity of the suit and the impossibility of defending successfully the rights of all the union members through a private action may justify the unusual step of relieving plaintiffs' investigating burden. And since the members or the organization are the prime beneficiaries of such a suit, it seems reasonable to assess the costs of monitorship against the association. On the other hand, the risk of paying litigation expenses if the suit fails acts as a deterrent to member-plaintiffs who might otherwise bring spurious or trivial actions. In a corporate context, this policy is expressed in some state laws which require stockholders with minimal holdings to post a bond for litigation expenses. ${ }^{22}$ But this danger would seem minor if monitorship is imposed through a consent decree, for defendants have impliedly recognized merit in the suit by acquiescing in the remedy.

In the future, mutual consent to a monitorship will probably be confined to a few exceptional situations. Plaintiffs suing in good faith may find it advantageous to give up control over the suit in order to escape potential liability for costs. ${ }^{93}$ Plaintiffs will not lose all voice in the suit, since there is nothing in monitor procedures to prevent their appearance and argument when the court later holds hearings on monitor recommendations. And defendants may sometimes approve a monitorship when a more drastic remedy, such as receivership or removal from office, is threatened. ${ }^{94}$ Or, defendants themselves may wish to "clean house," especially if the complaint does not implicate all the officers of the association. But in the large number of suits attacking the incumbent management directly, the defendants will hestitate to remove plaintiff's financial handicaps. The contrary action of the Teamster defendants is probably not indicative of future defendant response, for the true nature of the Board of Monitors did not become apparent until after the decree was formulated.

In the cases where a consent decree cannot be obtained, the court must determine whether it can impose a monitorship without consent. In essence, such a procedure would resemble that of administrative agencies such as the NLRB. The complainant brings certain facts to the attention of the agency or court, which, after a preliminary determination of the suit's merit, orders its staff to investigate the complaint and prosecute it. ${ }^{95}$ The final hearing before the agency or court is an adversary proceeding between the defendant and the

92. E.g., N.Y. Gen. Corp. LAw \& 61-b; Cohen v. Beneficial Indus. Loan Corp., 337 U.S. 541, 544-45 (1949); Lattin, Corforations 384-88 (1959).

93. Livingston, The American Stockerolder 49-59 (1958).

94. Plaintiffs in the Teamsters case, for example, appear to have consented partly because of the threat to remove them from office. As plaintiffs put it, they assented so that the results of the 1957 convention would not be "thwarted for an extended period, with the Union remaining under the leadership of its former General President, Dave Beck, and under the government of a rejected constitution." Brief for Appellants in Court of Appeals, p. 4 (1959).

95. Davis, Administrative Law $\$ \$ 3.01-3.03$ (1958). 
prosecuting officer of the court or agency, with the plaintiff as intervenor. ${ }^{96}$ A nonconsent monitorship, however, would go one step further. While the cost of an agency investigation is placed upon the general public, the cost of monitor investigation would fall upon the organization nominally the defendant.

The fundamental objection to a nonconsent monitorship is its breach with the adversary process, especially its departure from the concept that a court must decide cases according to the interests of the parties as the parties present them, because only the parties know best what their interests demand. ${ }^{97}$ But the adversary requirement has been set aside in the establishment of administrative agencies, where it was found that the interests to be protectedgenerally those of the public-are so diverse that they cannot adequately be defended in a private suit.98 The members of an association represented in a class action by a few of their number might be considered as a smaller kind of public, equally unable to make their "interests" known in private litigation.

But the analogy to administrative agencies is defective. Unlike an administrative agency which continuously performs prosecutory activities, a court of general jurisdiction must also be concerned in all of its litigation with its appearance as a noninitiating, impartial arbiter. Involvement as an active participant in private disputes, even if a clean separation of investigating and judicial functions is made, may detract from this aura of impartiality; the impression of administrative agencies as partisans owes much of its force to their active involvement.99

For a court or its officers to initiate either a suit or an investigation implies that they have already formulated a tentative view of the facts, an implication incompatible with the court's role as a neutral. While the agency perhaps can afford this appearance and indeed may enjoy it, courts of general jurisdiction cannot. The experience of other judicial systems, demonstrating that courts can function effectively outside the adversary process, is probably not an accurate gauge of the impact which nonadversary procedures would have upon American courts, for in this country such judicial conduct would be an exception to the accepted system and would more readily raise the inference of partisanship.

The practical difficulty of evaluating the merits of any particular complaint also counsels against adoption of nonconsent monitorships, for the court must reach its decision with something less than full proof of the allegations. A requirement of full proof would leave little investigation for monitors to do, and plaintiffs would be sure enough of victory to continue the suit under their

96. Id. at $\S \S 7.01-7.02,7.05,22.07$; Administrative Procedure Act $\S 5(\mathrm{~b}), 60$ Stat. 239 (1946), 5 U.S.C. 1004 (b) (1958).

97. Field \& Kaplan, Matertals on Civil Procedure 166 (1953). But see Arnold, Syarbols of Government 172-74, 183-85 (1935).

98. Landis, The Administrative Process 30-40 (1938); Davis, Adninistrative LAW $\S 1.05$ (1958).

99. Id. at $\$ \S 1.06,301$. 
own expense and control. An agency may evidence its vigor by the occasional prosecution of a weak complaint. But the court's prestige will suffer if it errs by appointing a monitor without adequate justification and thereby unjustly shifts the investigation burden and unnecessarily scrutinizes the affairs of a private organization. Such errors might also encourage frivolous suits by removing the cost deterrent. These considerations suggest that future monitorships should be confined to appointments under a consent decree.

\section{The Effectiveness of Monitors}

\section{The Teamster Monitors}

The pervasive role of the Teamsters in the national economy and the internal structure of this union offered an unusual context for judicial intervention. The Teamsters, a wealthy and politically active union boasting a membership exceeding one and a half million workers, ${ }^{100}$ is the largest international union in the United States. Not affiliated with the AFL-CIO, the union usually disassociates itself from the general labor movement. ${ }^{101}$ The industries served by the Teamsters perform diverse economic activities, and, being generally small and oriented to local markets, are frequently in an inferior position relative to the union. ${ }^{102}$ The International is both miliant and autocratic $;^{103}$ the president enjoys extensive authority and great emergency power. ${ }^{104}$ Although the primary strength of this union is in the locals, the well-organized International is a strongly cohesive force in union affairs, and the union has always presented a unified front to any hostile outside group. ${ }^{105}$

The task of supervising this formidable organization has been impeded by a steady deterioration in Teamster-Monitor relations. The General Executive Board, through editorials in the International Teamster, have charged the Monitors with improper interferences in union affairs and with wasteful expenditures. ${ }^{106}$ In turn, the Monitors have accused the Teamsters of harassment, claiming that they have flooded the Monitor office with trivial, timeconsuming correspondence, delayed payment of Monitor salaries, and refused even minor requests. ${ }^{107}$ Teamster supported petitions seeking to remove several members of the Board of Monitors, including the chairman, have been

100. Letter, The TeAmsters Union 71, 263 (1957) [hereinafter cited as LeIter].

101. See, e.g., Gillingham, The Teamsters Union on the West Coast 40 (1956) [hereinafter cited as GILLINGHAM].

102. Cf. Leiter 132-34, 164; GillinghaM 87.

103. LETTER 263.

104. Id. at 73 .

105. Id. at $58,106,264-65$.

106. See The International Teamster, Sept. 1958, p. 16; id. Oct. 1958, pp. 8-9.

107. A spokesman for the court-appointed Monitors said the case backlog is of "Hoffa's own making." ... He charged that Hoffa has engaged in "obstructionist tactics"....

Hoffa Criticizes Delays, Costs of Montorship, 45 Lab. ReL. Rep. 173, 174 (1959). 
filed with the district court. ${ }^{108}$ And a nightmarish deluge of procedural motions has complicated the basic dispute over the interpretation of the consent decree. There have been thirty-five appeals from the district court and several petitions to the Supreme Court. Recently twenty-four motions were pending in the district court; earlier, nineteen petitions simultaneously competed for the attention of the appellate court. ${ }^{109}$ Litigation has dealt with such inspiring matters as the right of the Monitors to issue press releases and the location of Monitor headquarters. ${ }^{110}$

The Board of Monitors did produce some salutary results. An informal request that the Teamsters employ an independent accounting firm to institute a financial and accounting survey was acceded to by the International. ${ }^{111}$ And the union consented to several of the formal Monitor Orders of Recommendation without resistence; they accepted a set of rules for local elections drafted after months of negotiation, and reinstated several union members who had been expelled.112 Ten Orders of Recommendation, at first resisted by the Teamsters, were accepted after judicial approval and enforcement. These orders compelled the Teamsters to postpone particular local elections, file charges against corrupt local officials, clarify qualifications for election to local office, and publish all Monitor recommendations in the International's newspaper. ${ }^{113}$ But these achievements scarcely amount to significant reform. Despite two years of Monitor activity, the basic objective-a new convention with democratic procedures-has not been fulfilled.114 The Monitors have neither dealt effectively with corruption, instituted democratic procedures, amended the International constitution, nor implemented a model code of local by-laws. ${ }^{115}$ Monitor treatment of individual union member complaints has also been generally unsatisfactory. ${ }^{116}$ In addition, Monitor activitiy has consumed an exorbitant amount of court time and money; the latter cost, borne entirely by the Teamsters, may reach one-half million dollars. ${ }^{117}$

108. N.Y. Times, Feb. 14, 1960, § L, p. 68, col. 4; id., Feb. 16, 1960, p. 30, col. 6, 7; see $i d .$, Feb. 25,1960 , p. 16, col. 4 .

109. Interview with Raymond W. Bergan, counsel for the International Board of Teamsters, in Washington, D.C., August 1960.

110. N.Y. Times, Jan. 31, 1960, § L, p. 31, col. 3; id., March 8, 1960, p. 21, col. 1.

111. Brief for Appellants, p. 64, Brief for Board of Monitors, p. 27, English v. Cunningham, 269 F.2d 517 (D.C. Cir. 1959).

112. Ibid; see 45 L.R.R.M 3 (1959).

113. English v. Cunningham, 269 F.2d 517, 527-32 (D.C. Cir. 1959).

114. Cunningham v. English, 175 F. Supp. 764, 768 (D.D.C. 1958).

115. See Letter of Resignation From Martin F. O'Donoghue to Judge Dickenson Lettes, July 9, 1960 (mimeo) (" 'The things we started to do are still to be done,' Mr. Smith said. 'Basic to a convention is action on the bums at the local level.' ") N.Y. Times, June 3, 1960, p. 14, col. 5.

116. Hoffa Criticizes Delays, Costs of Montorship, 45 L.R.R.M. 173; Interview with Lawrence Cohen, Staff Member of Board of Monitors, in New Haven, Conn., February 2, 1960 .

117. N.Y. Times, Feb. 25, 1960, p. 16, col. 4; The International Teamster, May 1960, p. 22. 
The overall failure of the Teamster Monitorship is, in part, attributable to its uniqueness. Forced to formulate procedures by trial and error and to seek court approval at each stage, the Monitors have been administratively inefficient. And the Teamsters have been quick to test the legality of each new practice, further increasing the cost of and delay in Monitor operations. ${ }^{118}$ Confusion over the purpose of the Monitorship has compounded these administrative shortcomings. Although the Court of Appeals has held that the purpose, scope, and power of the Teamster Monitorship are governed by the consent decree, ${ }^{119}$ the imprecision and breadth of this instrument have diluted its value as a guide. ${ }^{120}$ Thus, the Teamsters have argued that the Monitors enjoy only those powers explicitly agreed upon, ${ }^{121}$ while the Board has based its authority on the permissibility of necessary modifications of the decree and their obligation as court officers to enforce it.. ${ }^{222}$ The decree has also invited impotency by the sheer size of the task it places before the Monitors. The number and variety of assigned objectives was overwhelming, ranging from general union democracy to elimination of individual instances of corruption. ${ }^{123}$ The enormity of the Teamsters Union adds to the difficulty, for it increases the number of problems which must be disposed of to achieve any single objective.

Additionally, the course of litigation has been influenced by the nonproperty character of many of plaintiffs' complaints. The general objectives of "democratic" elections and "fiduciary" obligations have called for monitor skills beyond those usually required of masters and receivers, and have intensified the difficulties in judicial evaluation of monitor performance.

The failure of the Teamster Monitors can also be traced to acute personal differences. Former chairman O'Donoghue conceived of the Monitor device as a potentially significant instrument for bringing democracy to the labor movement, and eventually viewed the ouster of Teamster President James Hoffa as a prerequisite for union reform. ${ }^{124}$ Hoffa has resisted all major Monitor attempts to tamper with Teamster personnel or procedures because, to him, the dynamic and powerful president of an effective, efficient organization, the Board is an officious intermeddler. ${ }^{125}$ And Hoffa found the chairmanship of O'Donoghue particularly distasteful since the chairman, prior to

118. See text accompanying note 109 supra.

Hoffa and a battery of lawyers have fought strenuously against almost every O'Donoghue move, bringing 35 separate actions to the Court of Appeals.

Washington Post, July 18, 1960, p. 1, col. 2. .

119. See note 18 supra.

120. See note 19 supra.

121. See The International Teamster, Oct. 1958, p. 8; Brief for Appellants, pp. 31, 37, English v. Cunningham, 269 F.2d 517 (D.C. Cir. 1959).

122. Brief for Board of Monitors, p. 75, English v. Cunningham, supra note 121 .

123. See notes 12-14 supra and accompanying text.

124. Affidavit of Martin F. O'Donoghue, May 1960, p. 5, filed in Cunningham v. English, Civil No. 2361-57, D.D.C. 1960.

125. See The International Teamster, Aug. 1960, p. 6; Mandelbaum, Teamster Monitorship: A Lesson for the Future, 20 FED. B.J. 125, 128. 
his Teamster-approved appointment to the Board, represented the Teamsters in an earlier stage of the instant litigation and may have had information damaging to his former clients. ${ }^{126}$

Even more serious than the Monitor-Teamster antagonism is the breakdown of intra-Board rapport. Godfrey Schmidt, the initial nominee of plaintiffs, openly quarreled over the proper scope of Monitor power with the Monitor nominated by the Teamsters. ${ }^{127}$ When Schmidt's successor refused to support an interim Monitor report supported by former Chairman O'Donoghue charging Hoffa with misfeasance, he was removed from office by Judge Letts but later reinstated by the Court of Appeals on the ground that the method of dismissal had been improper. ${ }^{128}$ William E. Bufalino, the current Teamsterdesignated Monitor, who was called by O'Donoghue a "tool for creating dissension," ${ }^{29}$ has himself charged the Monitor staff with refusing him access to Monitor correspondence and files. ${ }^{130}$ As a result of these and other skirmishes ${ }^{131}$ there is a total absence of harmony among the Board members. ${ }^{132}$

\section{In Internal Union Affairs}

Because of the sensitive nature of labor relations, and labor's generally suspicious and uncooperative attitude toward a historically hostile judiciary, ${ }^{133}$ judicial intervention in internal union affairs creates more serious problems

126. Interview with Raymond Bergan in Washington, D.C., Aug. 1960.

127. N.Y. Times, June 28,1959 , p. 1, col. 7.

128. N.Y. Times, June 3, 1960, p. 1, col. 2 (Smith reinstated).

129. New Haven Journal-Courier, June 1, 1960, p. 7, col. 3, 4.

130. Ibid.

Perhaps the most striking examples of this discord can be found in the first fully recorded conference of the Board of Monitors:

Mr. Buffalino: "I am being interrupted .... which is what I expected would happen that the Chairman would do." (p. 3)

"I do not intend to be used as a pawn by you, as Chairman. ..." (p. 8)

"I feel that I have been systematically and, I might say, effectively blacked out from many of the matters which were undertaken at the offices of the Board of Monitors. ..." (p. 10)

Mr. O'Donoghue: "And act like a lawyer and not a business agent of the Teamster's Union." (p. 16)

"... you come in here to harangue us." (p. 16) (p. 40)

"Stop pointing your finger-you will hit the stenographer. Now talk quietly."

"I said that I was not going to take any more abuse from you over the telephone or anywhere else." (p. 44)

131. N.Y. Times, March 5, 1960, p. 42, col. 2, (Maher and Smith "team up" against O'Donoghue on issue of charges against Hoffa); id., March 7, 1960, p. 12, col. 1; id., March 9, 1960, p. 29, col. 4.

132. Id., June 3, 1960, p. 1, col. 2.

133. See generally, Frankfurter \& Greene, The Labor Injunction (1930); Gregory, Labor aNd the LAW (1946). 
than interference with other associations. ${ }^{134}$ More than business management, labor union leadership on the international level relies to a great extent upon the personal confidence and loyalty of its members, ${ }^{135}$ and this cohesive force, essential to successful bargaining, may be weakened by the imposition of external authority. Intervention may cast a continuing stigma on all segments of the union regardless of guilt, place the tenure of the officers in doubt, offer a focal point for adverse public opinion and dissident local minorities, and deplete the union treasury. ${ }^{136}$ Or, if the intervention proves as ineffective as it was in the case of the Teamsters Monitors, it will further weaken the authority of the judiciary and may consolidate support for a possibly dishonest union administration.

Future use of Monitors in this area may be curtailed by the Labor Management Reporting Act of $1959,{ }^{137}$ which transfers to the Secretary of Labor a significant number of the functions which would be exercised by a Board of Monitors. Since a difference in procedures and remedies may produce different results, ${ }^{138}$ courts of equity should hesitate to use methods other than those outlined in the '59 Act, even though the court's policy objectives are in harmony with those of Congress; indeed, some monitor functions may be preempted by exclusive delegation to the secretary. ${ }^{139}$ The investigative activities of a Board of Monitors are made largely superfiuous, because the Secretary is explicitly authorized to investigate rank and file complaints relating to most titles of the act, and to prosecute actions for violations thereof. ${ }^{140}$ In addition, the Act contains extensive disclosure provisions which require unions periodically to file reports with the Secretary of Labor on administrative policies and financial condition. ${ }^{141}$ And if a violation of an election procedure has been proved before a court, section 402 (c) explicitly delegates to the Secretary of Labor the authority to direct and supervise a new election.

Some latitude remains, however. Where a local trusteeship has been maintained for more than eighteen months and continuance of the trusteeship is found necessary, the Act authorizes a court to "retain jurisdiction . . . on such conditions and for such period as it deems appropriate."142 In the ex-

134. See generally Chafee, The Internal Affairs of Associations Not for Profit, 43 HARV. L. REV. 993, 1023 (1930).

135. Lipset, Trow \& Coleman, Union Democracy 201-37 (1956).

136. See note 117 supra.

137. Labor-Management Reporting and Disclosure Act of 1959, 73 Stat. 519, 29 U.S.C.A. § 153, 158-60, 187, 401-531 (Supp. 1959) [hereinafter cited as LMRDA followed by the Stat. section].

138. Cf. New England Coal \& Coke Co. v. Rutland R. Co., 143 F.2d 179 (2d Cir. 1944) (bankruptcy statute precludes consent receivership).

139. See LMRDA $\$ 4$ (c) (discussed in text at note 141 infra); Garner v. Teamsters Union, 346 U.S. 485, 490-91 (1953) ; San Diego Building Trades Council v. Garmon, 359 U.S. 236 (1959).

140. LMRDA $\S \S 210,304,402,402$ (b).

141. LMRDA $\S 8202,203$.

142. LMRDA $\S 304(\mathrm{c})$. The trusteeships here referred to are those imposed by an 
ercise of this jurisdiction a Board of Monitors could conceivably be utilized to expedite discontinuance of the trusteeship, one of the functions actually assigned to the Teamster Monitors. Furthermore, a court might still call upon a Board of Monitors to perform certain well defined assignments such as drafting a new constitution or by-laws or instituting proper financial practices.

\section{In Nonlabor Controversies}

As a device for equitable intervention in and supervision of private organizations the Board of Monitors, its undesirability in internal union affairs notwithstanding, may be a useful judicial instrument in controversies less charged with hostility. Where legal remedies are inadequate because a complex fact situation necessitates a lengthy investigation of a specialized nature or some measure of judicial surveillance is called for, a device similar to the Teamster Monitors may be preferable to other forms of equitable relief. A receiver may be inappropriate because control or management of an enterprise or the transfer of title to property is not needed. And the court may prefer not to appoint a master if it wishes to take on certain investigatory duties normally performed by plaintiff, either because it is desirable to shift the financial burden from plaintiff or because the usual adversaries-and-formal-hearing process is felt to be cumbersome. ${ }^{143}$ In common with masters and receivers, monitors will provide expertness and technical ability to assist the court. In contrast to the other two devices, monitors may in the future benefit from the cooperation which was hoped for but never materialized in the Teamsters litigation.

Monitors will prove most useful where a class suit is brought by the members of an organization and the problems involved are technical or complex. They might be used, for example, in suits by members of an unincorporated fraternal or benevolent association to prevent mismanagement or distortion of the organization's purpose. ${ }^{144}$ Stockholder derivative actions could be assisted by a consent monitorship, providing that plaintiffs were willing to give up control of the suit and the possibility of legal fees concomitant to control. Monitors could also be used to investigate mutual accusations of fraud and improper solicitation in a corporate proxy fight.

Utilization of a Board of Monitors might also be considered in contract litigation. Lacking the ability to provide the continuing supervision necessary adequately to enforce a decree of specific performance, courts have denied requests for orders to operate a railroad, ${ }^{145}$ continue service in the carriage

international union over a local pursuant to the union constitution and usually to enforce a provision of that constitution.

143. To appoint a master to supervise the election would delegate the responsibility, but the master would face many of the same problems as the judge.

Cox, The Role of Law in Preserving Union Democracy, 72 HARv. L. REv. 609, 626 (1959).

144. See, e.g., Milasinovich v. Serbian Progressive Club, 369 Pa. 26, $84^{\circ}$ A.2d 571 (1951) (receiver appointed when corporate assets given to communist organizations).

145. Port Clinton R.R. v. Cleveland \& T.R.R., 13 Ohio St. 544 (Dist. Ct. 1862). 
of goods, ${ }^{146}$ mine and ship a specified quantity of coal, ${ }^{147}$ and repair or erect a building. ${ }^{148}$ In cases of this nature appointment of a board of monitors, which could oversee a technical situation over a long period of time and report on and prosecute violations of the decree, might make specific performance practicable. Independent monitor investigations would be less cumbersome than continual hearings before a master to hear plaintiff's complaints about daily performance. Additionally, if monitors succeed in their intended function of inducing cooperation of the parties, the court can supervise performance without the need to issue countless enforcing orders; the mere presence of monitors as court officers may help to secure on the spot compliance. While assessing costs of the monitorship against defendants may not be as justifiable as in the case of a suit by members of an organization, the different motives of parties to a specific performance decree may allow some flexibility in cost apportionment. ${ }^{149}$

\section{Summary}

In an effort to remedy the institutional inadequacy of courts and legislatures in dealing with complex disputes requiring continuing surveillance, the Board of Monitors was created. Failure of the Teamster experiment should not suggest rejection of monitorship as an equity technique. Further experience with this procedure may bring a clearer appreciation of the powers and functions most conducive to a successful monitorship; litigants and courts will then be able to frame more precise decrees which do not invite the constant, debilitating litigation inflicted on the Teamster Monitors. Experience may also lead to more selective application of monitorship, avoiding its use where the job is too large or where the likelihood of the litigants' cooperation appears slight. Finally, some procedural reforms might be undertaken, such as the addition of the supoena power ${ }^{150}$ and elimination of intra-board personality clashes, either by the selection of an all neutral panel or by the use of a one man board..$^{151}$

146. Atlanta \& W.P.R.R. v. Speer, 32 Ga. 550 (1861).

147. George E. Warren Co. v. A. L. Black Coal Co., 85 W. Va. 684, 102 S.E. 672 (1920).

148. Beck v. Allison, 56 N.Y. 366 (1874); see 5 Corbin, Contracts $\S 1172$ (1951).

149. For example, if plaintiff desires specific performance instead of damages, but the court will not order specific performance without the ancillary monitorship, plaintiff may be induced to accept partial costs.

150. There is some question as to whether monitors could properly be given subpoeria power, since Federal Rules of Civil Procedure 45(e) (1), 30(9), 31 (a), and 26(9), which deal with subpoenas and discovery, all refer to parties and not court appointees. Cf. NLRB v. Duval Jewelry Co., 357 U.S. 1 (1958).

151. In addition to the practical reasons for a neutral board, the practice, when a class action has been instituted, of delegating the duty to protect that class to a board which includes a representative of an adverse party, seems of questionable legality. Cf. Boyd v. Brown, 79 Colo. 568, 247 Pac. 181 (1926) ; New York, P. \& O.R.R. v. New York, L.E. \& W.R.R., 58 Fed. 268 (C.C.N.D. Ohio 1893) ; Graham v. Hundley Dry Goods Co., 
Because the appointment of a Board is a new remedy, the principles developed in receivership and master cases are not binding. ${ }^{152}$ But like these devices, monitorship is a drastic remedy. In addition to the potentially exorbitant cost to the organization, ${ }^{153}$ the appointment of judicial officers to investigate may damage the organization's credit and discourage persons from dealing with it. $^{164}$ Also, to the extent that courts are tempted to rubber stamp decisions of their appointed officers, widespread use of monitors will undermine the prestige and the moral authority of the courts' decrees. ${ }^{165}$ Thus, the court should consider, as it does in receivership and master cases : the need for personal action, specialized knowledge or continuous supervision, the possible damage to the organization, the expected duration of the supervision, the intent of the parties, the nature of the interest threatened, and the probable achievements of the court officer in the context of the particular litigation.

177 S.W. 600 (Mo. Sup. Ct. 1915) ; Bartelt v. Smith, 145 Wis. 31, 129 N.W. 782 (1911). See, e.g., Hill, Consent Receiverships in Federal Equity Practice, 11 CHI.-Kent L. Rev. 267, 275 (1933) (litigants should not suggest the individuals to be named as receivers). But see 19 A.B.A.J. 7, 10 (1933). Compare 27 ILI. L. REv. 48 (1932) (masters should not be picked by litigants).

152. [T] The Chancellor always has had, and always must have, a certain power and freedom of action, not possessed by the courts of law, of adapting the doctrines which he administers.

1 Pomeroy, Equity Jurisprudence $\$ 60$ (5th ed. 1941).

153. It is a matter of common knowledge that references greatly increase the cost of litigation and delay and postpone the end of litigation. References are expensive and time consuming.

Adventures in Good Eating, Inc. v. Best Places to Eat, 131 F.2d 809, 815 (7th Cir. 1942) ; Carey v. Dalgarn Constr. Co., 171 La. 246, 255, 130 So. 344, 348 (1930) (expense of receivership important).

154. Cf. Pomeroy, EQuity Jurisprudence $\$ 1484$ (4th ed.).

155. Adventures in Good Eating, Inc. v. Best Places to Eat, supra note 154:

Likewise, the litigants prefer, and are entitled to, the decision of the judge of the court before whom the suit is brought. Greater confldence in the outcome of the contest and more respect for the judgment of the court arise when the trial is by the judge.

See also Kaufman, Masters in the Federal Courts: Rule 53, 58 Colum. L. REv. 452, 453 (1958). 